\title{
Inclusion in Preschools and Elementary Schools in Japan
}

\section{Douglas Jarrell \\ Nagoya Women's University}

\section{Reference Data:}

Jarrell, D. (2019). Inclusion in preschools and elementary schools in Japan. In P. Clements, A. Krause, \& P. Bennett (Eds.), Diversity and inclusion. Tokyo: JALT.

While Japan's population has begun to shrink and age simultaneously, the number of foreigners moving to Japan continues to grow. This influx of "newcomers" has led to an increase in the number of foreign children in the Japanese school system. This is not a new trend; it began during the bubble economy in the late 1980s and early 1990s. Now, however, their numbers have increased to the point where their special needs can no longer be ignored. In this paper I look at the Japanese school system from the point of view of a diverse group of foreign parents and seek to find ways to facilitate their children's inclusion through better communication.

日本の人口が同時に減少と高齢化に悩まされる中、在日外国人が増え続けている。「ニーカーマー」の増加に伴い、日本 の学校に外国人の子どもも增加している。最近の傾向ではなくハンル経済の頃(1980年代終わり〜1990年代初め)から始まっ たが、今では子どもの数も多くなり、彼らの必要とする特別援助を無視することはできなくなつてきている。本論文では、複数 の外国人保護者の視点から見た日本の教育現場を考察し、子どもの受け入れを促すためにより良いコミユニケーション手段 を模索する。

here has been a steady increase in the number of foreign residents in Japan, and L this trend is likely to continue as Japan's working population shrinks due to the low birthrate. The Japanese government, worried about an impending labor shortage, has pushed ahead with legislation to allow more foreign workers to enter the country in order to take jobs in the construction, farming, and nursing sectors where the shortages are most acute ("Japan eases immigration," 2018). There are already a large number of foreign nationals in the Japanese preschool and school system, and the number is likely to increase. In this paper I seek to discover some of the problems that foreign parents and their children face in Japanese schools. Although there have been studies in this area, there is a lack of firsthand information from the involved parents themselves. In order to get a clearer picture of these difficulties, I carried out a small-scale survey of parents in July 2017. Results indicate that certain communication strategies can help to improve the situation and overcome problems arising from language deficiencies.

\section{Background}

The largest non-Japanese ethnic group at the beginning of the 1990s was the Korean community. It was a relatively stable group of people, many of whom had been born and grew up in Japan (Statistics Japan, 2010). Then, during the bubble economy 30 years ago, job opportunities were plentiful. The government decided to offer people with Japanese ancestry easy entry into Japan, and many third- and fourth-generation Japanese from South America came to work mainly in the automobile industry. The Brazilians were the largest group of "newcomers," and their population rose to over 300,000 in 2006 (McKenzie \& Salcedo, 2009), but numbers fell by one third quickly after what is known in Japan as the "Lehman shock," the worldwide economic recession of 2008 (Sieg \& Miyazaki, 2018). Nevertheless, the foreign population soon returned to its pre-Lehman shock number in 2015 and has continued to increase. Figure 1 shows fluctuations in the number of foreign residents from 2007 (H19) to 2016 (H28). Now Chinese newcomers make up the largest ethnic group. The most recent figures from the Japanese Ministry of Justice (Figure 2) show that other groups from Asia such as Filipinos and Vietnamese are an increasingly large proportion of foreign residents. 


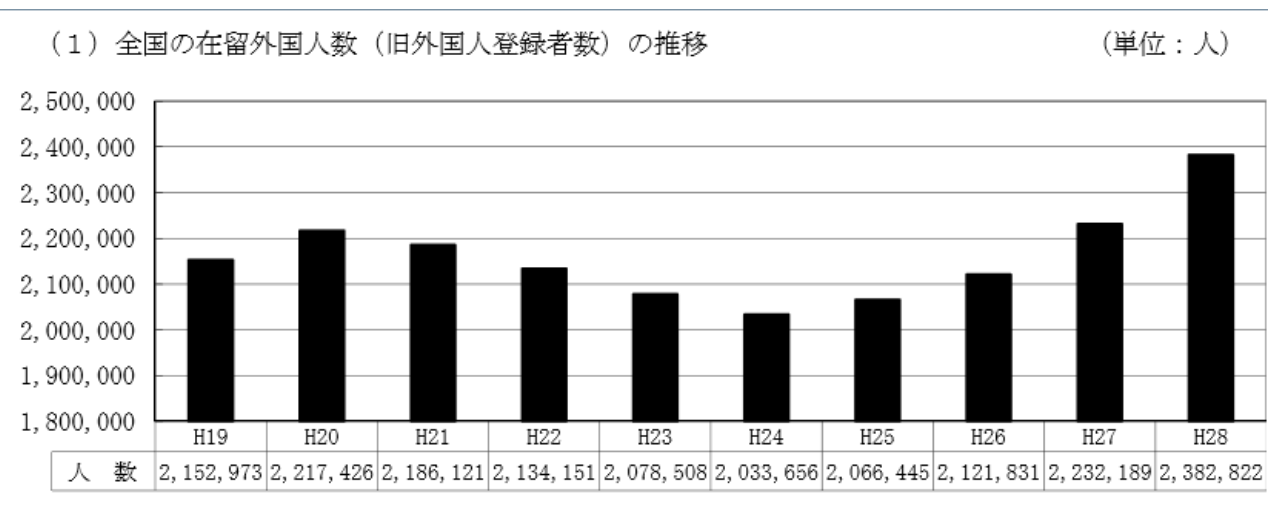

Figure 1. Number of foreigners living in Japan (Ministry of Justice, 2016). H19 = 2007; $\mathrm{H} 28=2016$

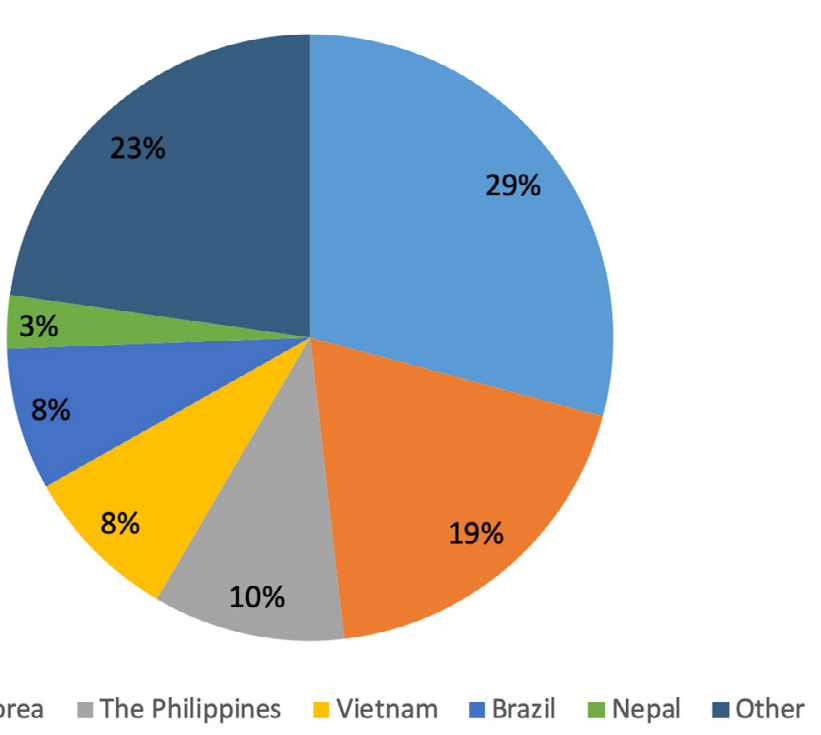

Figure 2. Foreign residents in Japan (Ministry of Justice, 2017).
The number of foreign children who need help with the Japanese language is increasing in every kind of school. Numbers are especially large in elementary schools which saw a 50\% increase: from 15,946 to 22,156 between 2006 and 2016 (Figure 3).

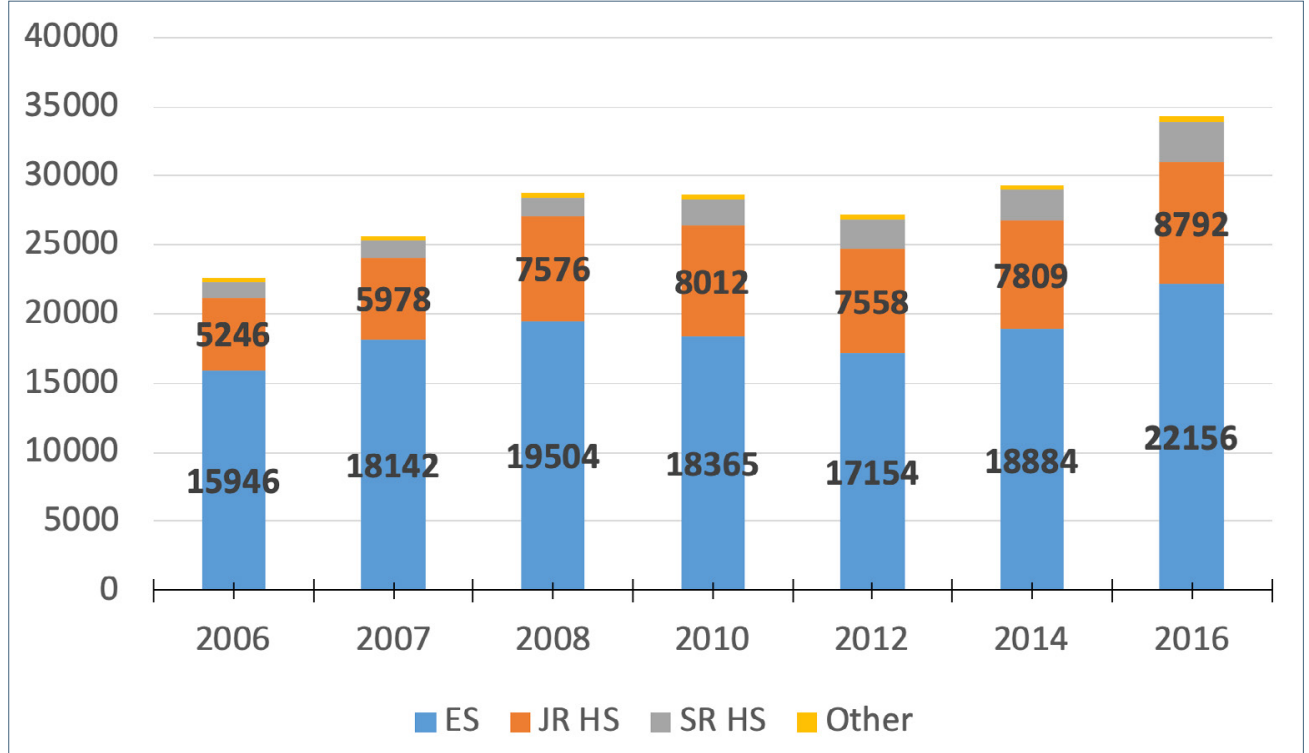

Figure 3. Number of children needing help with Japanese. ES = elementary school, JR HS = junior high school, SR HS = senior high school (translated from the original figure in MEXT, 2016)

There have been several studies dealing with the problems that these newcomers face in schools. Castro-Vazquez (2009) looked at three immigrant children from Latin America in a study from 2003 to 2006. In particular, the study examined the effectiveness of their Japanese-language tutoring program and concluded that lack of a strong assimilation policy, homogenous and standard teaching, and ethnic and gender assumptions prevented the program from being effective.

Miyajima and Ota (2012) noted that the requirement to attend school from the ages of 6 to 15, or until they complete junior high school, does not extend to children with foreign nationality. Many schools at the time of their 2004 survey did not automatically enroll the children in their district. Instead, the families had to apply for their children 
to go to school and get the approval of the local school board. Families that did not know about the process were unable to send their children to school. In one city in Gifu Prefecture with a large Brazilian population, the truancy rate rose to $7.2 \%$. They noted that children who did enter school often dropped out due to poor Japanese language skills and bullying.

Since that time, many local areas and school districts have become more aware of the problems and implemented changes. Information is translated before it is sent out, there are a growing number of Japanese classes for foreign children, and schools hire interpreters to ease communication with parents who are unable to speak Japanese.

In order to get a more detailed picture of the difficulties that foreign parents and their children face when dealing with the Japanese school system, I carried out a small survey of people from seven different countries: U.S.A., China, the Philippines, Gambia, Indonesia, Nepal, and Uzbekistan. All were parents of children who were in or had been through the Japanese school system.

\section{Method}

In July 2017, I sent out a written survey (see Appendix) to seven parents of different nationalities. They were asked about their children's experiences in the Japanese school system from preschool through high school. Other questions sought to find out their mode of communication with the school and communication difficulties they may have encountered. They were also asked to describe any differences they noted between Japanese education and that of their own country. Finally, they were asked about the treatment of their children by the school and by other students.

Afterwards, 30-minute interviews were conducted to confirm the information on the written surveys and elicit more details. I had face-to-face interviews with the respondents from the U.S.A., Gambia, Indonesia, and Nepal. The respondents from China and the Philippines were only available for phone interviews. The respondent from Uzbekistan was unavailable for an interview and only sent responses via email. The interviews were not recorded, but I took notes and wrote out a summary that the respondents reviewed.

Table 1 shows the basic data about the families interviewed. Letters have been assigned to the individuals for the purpose of anonymity and easy reference. Children who went to daycare entered before the age of 3 .
Table 1. Respondents' Basic Information

\begin{tabular}{llllllllll}
\hline Letter & Country & G & Sp & Ch 1 & S, EA & Ch 2 & S, EA & Ch 3 & S, EA \\
\hline A & USA & F & JP & Boy 6 & K, 5 & & & & \\
B & CH & M & CH & Girl 16 & K, 3 & Girl 6 & K, 3 & & \\
C & PH & F & PH & Girl 8 & DC & Girl 3 & DC & & \\
D & GB & F & GB & Boy 25 & DC & Girl 22 & DC & & \\
E & IND & M & JP & Boy 13 & K & Girl 11 & DC & Girl 7 & DC \\
F & NP & F & NP & Boy 16 & ES, 9 & Boy 6 & DC & Girl 5 & DC \\
G & UZ & F & UZ & $\begin{array}{l}\text { Data from } \\
\text { several }\end{array}$ & & & & & \\
& & & & & & & \\
& & & & & & & & \\
& fambek & & & & &
\end{tabular}

Note. $\mathrm{G}=$ gender; $\mathrm{Sp}=$ nationality of spouse; $\mathrm{Ch}=$ child; $\mathrm{S}, \mathrm{EA}=$ school and entry age; $\mathrm{K}=$ kindergarten (yochien); $\mathrm{DC}=$ daycare (hoikuen); $\mathrm{ES}=$ elementary school; $\mathrm{CH}=\mathrm{China} ; \mathrm{PH}=$ Philippines; GB = Gambia; IND = Indonesian; NP = Nepal; UZ = Uzbekistan .

Ms A had her son before coming to Japan, and when she arrived, neither she nor her son could speak Japanese. The father was living away from them most of the time and was not involved in communication with the son's schools. She enrolled her son in an international kindergarten but then moved him to a local kindergarten.

Mr. B came to Japan together with his wife as foreign students. They had one daughter at the time. They could not speak Japanese when they arrived, but the university introduced them to a daycare center that was accustomed to caring for foreign children.

Ms C came to Japan with her husband and daughter. Both worked full-time, but neither could speak Japanese when they arrived. Ms C's elementary school grade- 6 niece was fluent in Japanese and often translated for them when they communicated with the daycare center or elementary school.

Ms D and her husband had their children after they arrived in Japan. They didn't speak Japanese at first but gradually learned it. She did not learn to read Japanese, so written communications were taken care of by her husband. Both children spoke Japanese from the time they started preschool. 
Mr. E came as a graduate student and had learned Japanese by the time he met and married his wife. All of his children spoke Japanese when they started daycare.

Mr. F has been working in Japan for 20 years. He has learned to speak the language but is too busy to learn to read and write. His wife joined him in Japan when their son was 9. The other two children were born in Japan and spoke Japanese fluently when they started daycare.

Ms G decided to collect responses from a number of Uzbek friends instead of giving her own individual responses. There is a drawback to one respondent summarizing for a group: Individual interpretations can lead to a layer of bias. In this case, however, the author felt that her summary helped to highlight the diversity within Islam in a way that a single response could not. Religious issues were not discussed by other respondents.

\section{Results}

The results have been categorized as follows: communication issues, school culture and rules, limited Japanese language support, bullying and teachers, and school practices.

\section{Communication Issues}

Lack of Japanese ability on the part of the parents and lack of foreign language ability support among school staff and parents were seen as a major obstacle to communication. Another obstacle mentioned was the reliance on written communication between schools and parents.

\section{Lack of Language Ability}

- Ms C could not understand what the teachers told her in conferences with other parents. She used Google Translate to interpret the messages from the daycare center, but the translations were often unclear. She ended up bringing the wrong things to the center (e.g., a hand towel instead of a bath towel) and had to take her child home to get the correct things. Now there are translators at elementary school, so she no longer has the communication problems that she had when her first daughter started school.

- Ms A noticed that Japanese teachers and parents avoided coming into contact with her and attributed it to a lack of confidence in their English skills. She thought that they needed to try harder to communicate and use other communication strategies such as gesturing to get their points across.
- Mr. B felt he was well taken care of by his university. He was very happy with the kindergarten, and he and his wife had few communication problems once they learned basic Japanese. His daughter learned to speak Japanese quickly, and by the 6th month she had started to respond in Japanese rather than in Chinese.

Reliance on Written Communication

- Ms D thought there was too much paperwork and an overreliance on writing when communicating with parents.

- Mr. F complained about the amount of written communication and feels that this is the reason that mistakes are made. He and his wife had to rely on Japanese friends for translations.

\section{School Culture and Rules}

A number of the respondents mentioned that schools assume a knowledge of the school system and its rules. In many cases, the parents know neither and need to be told. Another point brought up by several of the respondents was that certain rules are simply not appropriate for the growing diversity within Japanese schools.

\section{Unfamiliarity With the Rules}

- As Ms A pointed out, people from other cultures are unfamiliar with many things. They do the wrong thing because they don't know. Teachers need to educate them by telling them directly.

- Ms C was reluctant to let her daughter be involved in the Tanabata (star) Festival because she didn't know what it was. No one explained it to her.

- Mr. F explained that he and his wife would be asked to buy things for school for the next day. It was impossible for them because they worked late. He pointed out that this and other kinds of poor communication can lead to a vicious cycle: Foreigners don't know the rules, or they can't follow them. As a result, they look bad and are criticized. They resent the criticism, and both the school and the parents end up dissatisfied with each other. 
Rules Versus Diversity

Ms D's daughter wore cornrows, the proper hairstyle for girls going to school in West Africa. The school told her that the hairstyle was against the rules, but as she says, the rules are made for Japanese hair, not African hair.

- The daughter of one of Ms G's friends was told not to say Amin before or after eating as she did at home. She was told to only say itadakimasu and gochisosama deshita. She felt that her daughter should be allowed to say both.

- Ms G reported that because of Islamic dietary restrictions, food was often the major problem. The schools were understanding, and some substituted nonpork alternatives when the menu included pork. However, in most cases the parents ended up having to make a special lunch for their children on a regular basis.

- Ms G did not understand why there was a rule about the children not wearing coats with hoods. Once the teacher explained the dangers for the child, she understood and followed the rule.

- Ms G mentioned that one friend did not want her daughter to be seen naked by the male daycare helper, and the center made sure that he did not participate in changing her clothes.

\section{Limited Japanese Language Support}

This was a problem for children who came to Japan without any Japanese language background and entered the school system at the end of kindergarten or during elementary school.

- Ms A was unhappy with her son's school because she felt that they didn't provide the extra Japanese support that he was promised. He knew words in English but not in Japanese (e.g., peacock) and would get discouraged by all the red marks on his tests.

- Mr. F's eldest child entered elementary school at the age of 9 without any Japanese background. The school had no Japanese language classroom, and Mr. F. felt that the teacher made no attempt to give him homework at his level. The boy sat through class without understanding anything. Mr. F had to go outside the school to find a tutor, and it took his son 6 years to catch up.

\section{Bullying and Teachers}

Different appearances, in this case skin color, led to bullying by other children. Some teachers stereotyped the children and showed a lack of proactiveness to prevent bullying.

\section{Bullying}

- Ms A and Ms D are black. Ms C and Mr. E are dark-skinned. All of their children were teased or bullied by the other children at some point because of the color of their skin.

- As Ms C's daughter developed friendships with her classmates, she had fewer problems.

- Mr. E's son was elected as the intercity track and field representative for his elementary school, leading to greater acceptance among his classmates.

\section{Teachers}

The respondents reported that most teachers were understanding, but Ms D mentioned that teachers did not try to prevent problems. They only reacted once a problem had arisen. She felt that they could have been more proactive.

- Ms D felt her son was pushed to participate in sports. She thought this was because there is a stereotype that black people are good at sports.

- Mr. E said that although some children teased his son because of his dark skin, the teachers often took his son's side when there was a fight.

\section{School Practices}

- Mr. B thinks that Japanese elementary school children are not required to study and that they have more discipline problems than in China.

- Both Mr. B and Ms G were shocked at first that children didn't bundle up in warm clothes when they were playing outside in winter, but they soon realized that this practice wasn't harmful to the children. If fact, it was probably good for their health.

- Ms D feels that the school system is good, and the schools provide everything the children need to study. Like Mr. B, however, she feels that the teachers don't have enough authority and there are discipline problems. 
- Mr. E said that there are more parent-teacher meetings in Japan, and he praised Japanese education for fostering teamwork and responsibility-the older children look after the younger children when they go to school in groups, and everyone cleans their classroom.

\section{Conclusion}

Although the Japanese educational system is gradually adapting to the increase in foreign children, there still exist problems that are common to most foreign parents who send their children to Japanese schools. Communication is perhaps the biggest problem. Support for parents with poor Japanese language skills may still be lacking, and the traditional reliance on written communication between teachers and parents only exacerbates the problem. Even when foreign parents have some Japanese speaking ability, they often are not literate and cannot understand the frequent written messages from the school.

One solution to this problem can be seen in the approach that Chiba City takes when dealing with the many ethnic groups that live within the city limits. There are more than 100 different nationalities in Chiba, and it does not have the financial resources to hire interpreters for every language. Instead, the city has devised a simplified Japanese system. Results of a survey show that information in typical written Japanese is understood by $36 \%$ of the respondents whereas by writing in a simple spoken style, understanding reached 90\% (Chiba City International Association, n.d.). This technique could provide a partial solution to the problem of relying on written communication.

Schools need to understand that foreign parents have not been through the Japanese school system themselves and therefore do not have the same background knowledge of school culture that Japanese parents have. Parents need to be told directly and clearly what is expected of them and have school events explained to them. Visual representation is one area that can help. Including photographs and illustrations can avoid misinterpretations that arise from generic terms such as towel or field trip.

Japanese-language support is important, especially for older children with limited Japanese ability. More and more schools in districts with large foreign populations have Japanese classrooms where students can go for special tutoring during kokugo (Japanese) classes. In schools where there are few foreign children, however, there may not be the resources available to provide such support. In those cases, teachers need to provide particular children with some kind of comprehensible classwork or homework that will allow them to use classroom time profitably while their Japanese ability is developing.
Stereotyping and bullying are difficult problems to solve. Sometimes the child can overcome them through friendships, which was the case for Ms C's daughter, or by becoming popular through extracurricular activities, as happened to the son of Mr. E who became the school representative in an interelementary sports competition. Mr. F did not actually mention bullying, but he hopes that the earlier introduction of English (foreign language activities) into the elementary school curriculum will create a more multiculturally friendly classroom and improve the communication skills of the teachers as well as the students.

Although this was a very restricted survey in terms of the number of respondents, the range of nationalities allows us to see diverse issues that confront foreign parents and their children in their dealings with Japanese educational institutions. The institutions are gradually adapting to the new reality of ethnic diversity in the classroom and are offering more accessibility for students and parents. At the same time, it is important to acknowledge that many difficulties that came up through this survey can only be dealt with on a personal level and will require time to solve.

\section{Bio Data}

Douglas Jarrell lives in Nagoya and has taught in a preservice teacher education program at Nagoya Women's University for 4 years. Although he retired at the end of March 2019, he is still interested in the impact of the growing non-Japanese population on Japanese educational institutions.

\section{References}

Castro-Vazquez, G. (2009). Immigrant children from Latin America at Japanese schools: Homogeneity, ethnicity, gender and language in education. Journal of Research in International Education, 8(1), 57-80. https://doi.org/10.1177/1475240908096484

Chiba City International Association. (n.d.). “やさしい日本語”を使っていますか? [Do you use “easy Japanese?’]. Retrieved from http://www.ccia-chiba.or.jp/index.php/yasashi-jp.html

Japan eases immigration rules for workers. (2018, December 8). BBC. Retrieved from https://www. bbc.com

McKenzie, D., \& Salcedo, A. (2009). Japanese-Brazilians and the future of Brazilian migration to Japan. International Migration. Retrieved from http://microdata.worldbank.org/index.php/ catalog/2231/download/32463 
MEXT. (2016). 日本語指導が必要な児童生徒の受入状況等に関する調査 (平成28年度)」の結果について [Results of a 2016 survey on the acceptance of children needing Japanese support (H28)]. Retrieved from http://www.mext.go.jp/b_menu/houdou/29/06/1386753.htm

Ministry of Justice. (2016). 在留外国人の状況等 [Statistics on foreign residents, 2016]. Retrieved from http://www.pref.ibaraki.jp/bugai/kokusai/tabunka/jpn/data/documents/02_ zennkokugaikokujinn.pdf

Ministry of Justice. (2017). 平成28年末現在における在留外国人数について(確定值) [Concerning the number of foreign residents at the end of 2016]. Retrieved from http://www.moj.go.jp/ nyuukokukanri/kouhou/nyuukokukanri04_00065.html

Miyajima, T., \& Ota, H. (Eds.). (2012). 外国の子供と日本の教育 [Foreign children and Japanese education]. Tokyo: Tokyo University Press.

Sieg, L., \& Miyazaki, A. (2018, December 6). As Japan considers allowing more foreigners, tiny rura town wants to go further. Reuters. Retrieved from https://www.reuters.com

Statistics Japan. (2010). South and North Korean residents in Japan. Retrieved from https://statsjapan.com/t/kiji/11618

\section{Appendix}

\section{Questionnaire}

This questionnaire is about experiences foreign parents have had with Japanese preschools/ kindergartens and elementary schools. If you have more than one child, please distinguish between your children in the answers (e.g., Child 1 went to preschool and elementary school, Child 2 is going to elementary school-she did not attend preschool in Japan.)

1. How many of your children have been schooled in Japan?

2. In Japan, did you send him/her/them to

(a) nursery/preschool/daycare (ほいくえん) (b) kindergarten (ようちえん) (c) only elementary school (しょうがっこう)

Child 1 :

Child 2:

Child 3:

Child 4:
3. How do/did you communicate with the school?
(a) face-to-face
(b) by communication notebook
(c) by phone

(d) other

4. How often do/did you communicate with the school? $\begin{array}{llll}\text { (a) every day } & \text { (b) } 2 \text { or } 3 \text { times/week } & \text { (c) once a week } & \text { (d) once a month }\end{array}$ (e) other

5. Who did you communicate with?

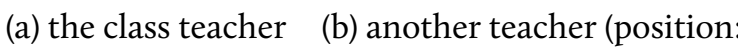
(c) the principal (or vice-principal)
(d) other

6. What was the content of the communication? (multiple answers are welcome) $\begin{array}{lll}\text { (a) academic work } & \text { (b) behavior } & \text { (c) school events (d) materials for class }\end{array}$ (e) other

7. What language was used?
(a) English
(b) Japanese
(c) other

8. Did you have any communication problems? If so, what were they?

9. Have you noticed differences in educational practices between Japanese schools and schools in your country? If so, please explain.

10. Are there any educational practices that you (a) don't understand, or (b) disagree with? 
11. How was your child treated by the classroom teacher?
(a) Fairly
(b) unfairly
(c) no opinion

Please elaborate if your answer is (b) or (c)

12. How was your child treated by the other children?
(a) Fairly
(b) unfairly
(c) no opinion

Please elaborate if your answer is (b) or (c)

13. Any other comments about your child(ren) and the Japanese educational system are welcome. 